\title{
LANDASAN DOKTRINER HAK GUGAT PEMERINTAH TERHADAP KERUGIAN LINGKUNGAN HIDUP DI INDONESIA
}

\author{
Dona Pratama Jonaidia, Andri G. Wibisanab
}

\begin{abstract}
ABSTRAK
Meskipun hak gugat pemerintah atas kerusakan dan/atau pencemaran lingkungan hidup telah menjadi hal yang lazim dewasa ini, namun di Indonesia landasan doktriner gugatan pemerintah tersebut masih jarang diperbincangkan. Dengan menggunakan metode penelitian hukum doktrinal, penelitian ini dimaksudkan untuk menganalisis landasan teoretis hak gugat pemerintah. Berdasarkan kajian analisis atas peraturan dan putusan pengadilan yang berlaku, serta melakukan perbandingan dengan doktrin-doktrin yang berlaku dalam tradisi common law, tulisan ini menemukan bahwa gugatan pemerintah telah diajukan dalam beberapa dasar teoretis yang berbeda, antara lain: i) pemerintah sebagai wali lingkungan hidup; ii) kerugian negara; dan iii) konsekuensi tanggung jawab negara terkait lingkungan hidup. Selain itu, hak gugat pemerintah di Indonesia memiliki karakteristik yang serupa dengan yang ditemukan dalam doktrin public trust dan doktrin parens patriae. Kemiripan ini membawa pada konsekuensi hukum bahwa gugatan pemerintah atas pencemaran harus ditujukan semata-mata untuk memulihkan lingkungan hidup yang mengalami kerusakan/pencemaran.
\end{abstract}

Kata kunci: doktrin; hak gugat pemerintah; kerugian lingkungan hidup.

\begin{abstract}
Despite the government's right to sue for environmental damage is a common practice in various countries nowadays, in Indonesia the theoretical basis of it is rare to be discussed. Using a doctrinal-research, this article analyzes the government's right to sue with prevailing laws and court rulings and compares it to several common law doctrines. This article finds the government's right to sue in Indonesia is based to three different theories, including: i) the government as a trustee of public natural resources; ii) state's damage; and iii) the tail of state's responsibility. In addition, the government's right to sue also shares similar characteristics found in the public trust doctrine and parens patriae doctrine. The similarities bring about the legal basis that the government's suit against pollution should primarily aim at restoration.
\end{abstract}

Keywords: doctrine; environmental damage; government's right to sue.

\footnotetext{
a Badan Pusat Statistik, Jalan dr. Sutomo 6-8 Jakarta, donajonaidi@gmail.com.

b Fakultas Hukum Universitas Indonesia, Jl. Prof. Mr Djokosoetono Depok 16424, email: andri.gunawan@ui.ac.id.
} 
Landasan Doktriner Hak Gugat Pemerintah Terhadap Kerugian Lingkungan Hidup di Indonesia

\section{PENDAHULUAN}

Pada tahun 2019, pemerintah melalui Kementerian Lingkungan Hidup dan Kehutanan (KLHK) tercatat telah mengajukan sebanyak 26 gugatan perdata atas kerusakan dan/atau pencemaran lingkungan, di mana 11 di antaranya telah berkekuatan hukum tetap (inkrach) dengan nilai putusan sebesar 19,4 triliun rupiah. ${ }^{1}$ Nilai tersebut dikalim sebagai nilai putusan perdata terbesar dalam sejarah Indonesia. Berdasarkan statistik Laporan Kinerja Direktorat Jenderal Penegakan Hukum KLHK, jumlah pendaftaran gugatan yang diajukan oleh KLHK ke pengadilan cenderung meningkat setiap tahunnya, bahkan capaian di tahun 2019 melebihi dari target yang ditentukan. ${ }^{2}$

Peningkatan kuantitas gugatan pemerintah terhadap peristiwa-peristiwa kerusakan dan/atau pencemaran lingkungan bukanlah tanpa sebab. Rezim Undang-Undang Nomor 23 Tahun 1997 (UU No. 23/1997) dan penggantinya, Undang-Undang Nomor 32 Tahun 2009 (UU No. 32/2009), telah membuka ruang bagi instansi pemerintah terkait dengan lingkungan untuk mengajukan gugatan terhadap pihak-pihak yang menyebabkan kerugian lingkungan hidup.

Meskipun dewasa ini norma dan implementasinya telah diterima secara luas, namun terkait dasar teoretis hak gugat pemerintah di Indonesia masih jarang dibincangkan oleh para sarjana. Pembahasan mengenai landasan hak gugat pemerintah umumnya ditautkan langsung dengan ketentuan dalam peraturan tertentu, misalnya Pasal 28H Undang-Undang Dasar Negara Republik Indonesia Tahun 1945 (UUD NRI Tahun 1945), Pasal 2 huruf a dan Pasal 90 ayat (1) UU No. 32/2009, tanpa menyinggung landasan doktrinernya secara mendalam.

Tulisan ini bermaksud untuk menjawab pertanyaan apakah alas teori dari tindakan pemerintah mengajukan gugatan atas kerugian lingkungan hidup di Indonesia. Upaya tersebut diperlukan bukan saja untuk menjustifikasi keberadaan hak gugat pemerintah dalam lapangan hukum Indonesia, namun pula untuk membantu dalam menilai, mengembangkan, atau memberi koreksi terhadap implementasinya. Untuk itu, tulisan ini akan menjelaskan mengapa doktrin public trust adalah padanan yang paling tepat sebagai landasan doktriner bagi hak gugat pemerintah di Indonesia. Terakhir, tulisan ini juga akan mengupas apa konsekuensi hukum dari doktrin public trust sebagai landasan doktriner hak gugat pemerintah di Indonesia.

\footnotetext{
${ }^{1}$ Kementerian Lingkungan HIdup dan Kehutanan RI, Laporan Kinerja 2019, Biro Perencanaan Kementerian Lingkungan Hidup dan Kehutanan, Jakarta: 2020, hlm. 48.

${ }^{2}$ Direktorat Jenderal Penegakan Hukum Lingkungan Hidup dan Kehutanan, Laporan Kinerja Tahun 2019, Setditjen Penegakan Hukum Lingkungan Hidup dan Kehutanan, Jakarta: 2020, hlm. 92.
} 


\section{METODE PENELITIAN}

Dengan menggunakan metode penelitian doktrinal dengan pendekatan perbandingan (comparation approach), tulisan ini secara khusus membahas persoalan dasar teoretis hak gugat pemerintah di Indonesia. Tulisan ini dibagi ke dalam beberapa bagian. Setelah bagian pendahuluan yang menjelaskan mengenai urgensi persolaan yang dibahas, Bagian B akan menerangkan perihal legal framework hak gugat pemerintah di Indonesia. Selanjutnya, Bagian C membahas terkait beberapa pandangan terhadap landasan doktriner hak gugat pemerintah di Indonesia. Sebelum pemaparan kesimpulan pada Bagian $\mathrm{E}$, tulisan ini menerangkan konsekuensi hukum penerapan hak gugat pemerintah berdasarkan asas tanggung jawab negara dan doktrin public trust.

\section{PEMBAHASAN}

\section{Dasar Yuridis Hak Gugat Pemerintah atas Kerugian Lingkungan di Indonesia}

Kemungkinan munculnya pembayaran ganti kerugian lingkungan kepada negara muncul pertama-tama dalam UU No. 4/1982 tentang Ketentuan-ketentuan Pokok Pengelolaan Lingkungan Hidup. ${ }^{3}$ Pasal 20 ayat (3) UU No. 4/1982 menentukan bahwa, "Barangsiapa merusak dan/atau mencemarkan lingkungan hidup memikul tanggung jawab membayar biaya-biaya pemulihan lingkungan hidup kepada negara." ${ }^{4}$

Secara lebih eksplisit, kewenangan gugatan pemerintah dimuat kembali dalam UU No. 23/1997 tentang Pengelolaan Lingkungan Hidup, tepatnya pada Pasal 37 ayat (2) yang menyatakan bahwa, "Jika diketahui bahwa masyarakat menderita karena akibat pencemaran dan/atau perusakan lingkungan hidup sedemikian rupa sehingga mempengaruhi perikehidupan pokok masyarakat, maka

3 UU No. 4/1982 dinilai sebagai tonggak sejarah politik lingkungan nasional karena melalui undang-undang tersebut pertama kali masalah lingkungan diatur secara nasional dengan materi yang luas dan terpadu dalam satu undang-undang, akan tetapi undang-undang tersebut tidak mengatur perihal penyelesaian sengketa lingkungan melalui gugatan pemerintah.

4 Penjelasan Pasal 20 ayat (3) UU No. 4/1982 menyatakan bahwa besar biaya pemulihan ditetapkan oleh suatu tim yang khusus dibentuk oleh pemerintah. Tim tersebut melakukan penelitian yang meliputi bidang ekologi, medis, sosial budaya, dan lain-lain yang diperlukan. Pada ayat 4 selanjutnya dinyatakan, "Tata cara penetapan dan pembayaran biaya pemulihan lingkungan hidup diatur dengan peraturan perundang-undangan."

Sementara itu, Lotulung menyebut bahwa Peraturan Pemerintah Nomor 20 Tahun 1990 tentang Pengendalian Pencemaran Air merupakan peraturan yang pertama kali memberikan pengaturan di Indonesia terhadap gugatan yang diajukan oleh pemerintah terhadap individu yang melakukan pencemaran terhadap tanah (lingkungan). ${ }^{4}$ Pasal 36 PP tersebut mengatur mengenai biaya pencegahan, penanggulangan, dan pemulihan pencemaran air, sebagaimana berbunyi sebagai berikut:

“(1) Biaya pencegahan penanggulangan dan pemulihan pencemaran air akibat suatu kegiatan dibebankan kepada penanggungjawab kegiatan yang bersangkutan;

(2) Apabila penanggung jawab kegiatan lalai melaksanakan penanggulangan pencemaran air sebagaimana dimaksud dalam ayat (1) atau melaksanakan tidak sebagaimana mestinya, maka Gubernur Kepala Daerah Tingkat I dapat melakukan atau memerintahkan untuk melakukan penanggulangan pencemaran tersebut atas beban pembiayaan penanggung jawab kegiatan yang bersangkutan. Apabila dipandang perlu Bupati/Walikotamadya Kepala Daerah Tingkat II atas nama Gubernur Kepala Daerah Tingkat II atas nama Gubernur Kepala daerah Tingkat I dapat mengambil tindakan sebagaimana dimaksud dalam ayat (2) atas beban pembiayaan kegiatan yang bersangkutan."

Memang tidak ada perumusan secara eksplisit atau expressis verbis bahwa gubernur dapat mengajukan tuntutan kembali atas biaya penanggulangan pencemaran air, namun menurut Lotulung secara hipotetis dapat terjadi suatu keadaan di mana Pemerintah Daerah Tingkat I atau Tingkat II telah melakukan atau telah memerintahkan untuk melakukan penanggulangan pencemaran air dengan biaya yang dibayar lebih dahulu (voorschieten) oleh pemerintah tetapi kemudian si penanggung jawab tetap tidak mau membayar biaya-biaya itu kembali kepada pemerintah. Dalam kondisi tersebut, menurutnya, tidak tertutup kemungkinan bagi pemerintah untuk melakukan atau menempuh upaya perdata dalam bentuk gugatan ganti rugi atas perbuatan melawan hukum terhadap si penanggung jawab. (Lihat: Paulus Effendi Lotulung, Penegakan Hukum Lingkungan Oleh Hakim Perdata, PT. Citra Aditya Bakti, Bandung: 1993). 
Landasan Doktriner Hak Gugat Pemerintah Terhadap Kerugian Lingkungan Hidup di Indonesia

instansi pemerintah yang bertanggung jawab di bidang lingkungan hidup dapat bertindak untuk kepentingan masyarakat." Rumusan tersebut menjadi dasar bagi pemerintah dapat mengajukan gugatan perdata atas kerugian yang timbul akibat kerusakan dan/atau pencemaran lingkungan.

Saat ini, hak gugat pemerintah atas kerusakan dan/atau pencemaran lingkungan bersandar pada ketentuan Pasal 90 ayat (1) UU No. 32/2009 yang berbunyi, "Instansi pemerintah dan pemerintah daerah yang bertanggung jawab di bidang lingkungan hidup berwenang mengajukan gugatan ganti rugi dan tindakan tertentu terhadap usaha dan/atau kegiatan yang menyebabkan pencemaran dan/atau kerusakan lingkungan hidup yang mengakibatkan kerugian lingkungan hidup." Dalam Penjelasannya disebutkan bahwa kerugian lingkungan hidup adalah kerugian yang timbul akibat pencemaran dan/atau kerusakan lingkungan hidup yang bukan merupakan hak milik privat. Sementara itu, tindakan tertentu diartikan sebagai tindakan pencegahan dan penanggulangan pencemaran dan/atau kerusakan serta pemulihan fungsi lingkungan hidup guna menjamin tidak akan terjadi atau terulangnya dampak negatif terhadap lingkungan hidup.

UU No. 32/2009 pula dalam Pasal 90 ayat (2) mengamanatkan bahwa ketentuan lebih lanjut mengenai kerugian lingkungan diatur dengan Peraturan Menteri, sehingga dengan itu diterbitkanlah beberapa Peraturan Menteri berkaitan dengan kerugian lingkungan, seperti: Permen LH Nomor 13 Tahun 2011 tentang Ganti Kerugian Akibat Pencemaran dan/atau Kerusakan Lingkungan Hidup yang telah diganti dengan Permen LH Nomor 7 Tahun 2014 (Permen LH No. 7/2014), Permen LH Nomor 14 Tahun 2012 tentang Panduan Valuasi Ekonomi Ekosistem Gambut (Permen LH Valuasi Gambut), dan Permen LH Nomor 15 Tahun 2012 tentang Panduan Valuasi Ekonomi Ekosistem Hutan (Permen LH Valuasi Hutan).

Selain itu, melalui Peraturan Ketua Mahkamah Agung Nomor 036/KMA/SK/II/2013 tentang Pemberlakuan Pedoman Penanganan Perkara Lingkungan Hidup (Keputusan KMA No. 36/KMA/SK/II/2013), rumusan Pasal 90 UU No. 32/2009 dijelaskan lebih lanjut dengan menentukan bahwa yang dimaksud dengan Instansi Pemerintah Pusat ialah Menteri Negara Lingkungan Hidup, Instansi Pemerintah Daerah Provinsi adalah Gubernur, yang dalam hal ini dapat dilimpahkan kepada Kepala Instansi Lingkungan Hidup Provinsi dengan surat kuasa dari Gubernur, Instansi Pemerintah Daerah Kabupaten/Kota adalah Bupati/Walikota dapat dilimpahkan kepada Kepala Instansi Lingkungan Hidup Tingkat Kabupaten/Kota dengan surat kuasa dari Bupati/Walikota. ${ }^{5}$

\footnotetext{
5 Apabila merujuk pada Keputusan Ketua Mahkamah Agung Nomor 036/KMA/SK/II/2013 tentang Pemberlakuan Pedoman Penanganan Perkara Lingkungan Hidup (Keputusan KMA No. 36/KMA/SK/II/2013), didapati beberapa gugatan yang diajukan oleh Kementerian Lingkungan Hidup dan bukan oleh Menteri Lingkungan Hidup, misalnya pada kasus Menteri LH melawan PT. Kallista Alam (Putusan Pengadilan Negeri Meulaboh No. 12/PDT.G/2012/PN.MBO. HIm. 3-4) dan kasus Menteri LH melawan PT. Surya Panen Subur (Putusan Pengadilan Negeri Jakarta Selatan No. 700/Pdt.G/2013/PN.Jkt.Sel, hlm. 2).

Selain itu, Keputusan KMA tersebut juga menerangkan soal frasa "dan" dalam Pasal 90 UU No. 32/2009 mesti dibaca sebagai alternatif, yang artinya bahwa instansi pemerintah (Menteri Lingkungan Hidup) dan/atau instansi Pemerintah Daerah (Gubernur atau Bupati atau Kepala Instansi Lingkungan Hidup Provinsi atau Kabupaten/Kota) dapat mengajukan gugatan ganti rugi dan/atau tindakan tertentu baik
} 


\section{Beberapa Pandangan Seputar Dasar Teoretis Hak Gugat Pemerintah di Indonesia}

Meskipun tidak dapat ditemukan dalam rumusan norma undang-undang yang memuatnya, namun dalam Rapat Dengar Pendapat Umum (RDPU), tercatat beberapa pihak pernah mengemukakan usulan dan pendapat berkenaan dengan dasar pemerintah melakukan gugatan atas kerusakan/pencemaran lingkungan. Hal ini terekam dalam catatan ICEL berikut ini:

“Dalam RDPU tanggal 13 Juli 2009, Prayekti dari ICEL mengusulkan agar hak pemerintah untuk menggugat mewakili masyarakat sebagaimana yang diatur dalam Pasal 37 UU No. 32 Tahun 2009 dihapus. Alasannya, seharusnya pemerintah menggugat mewakili kerugian negara, sedangkan masyarakat dapat mencari keadilan dengan hak gugat yang diberikan kepada mereka. Mas Achmad Santosa dalam RDPU tanggal 16 Juli kembali mempertegas agar hak gugat pemerintah untuk mewakili kepentingan masyarakat dihapus dan seharusnya pemerintah dapat menggugat lebih dari mewakili kerugian negara (misalnya: kerugian lingkungan). Usulan dari Prayekti dan Mas Achmad Santosa mendapat tanggapan dari Fachrudin Djaya dalam Rapat Panja tanggal 29 Juli 2009, yang menyebutkan bahwa sebaiknya pemerintah menggugat ketika negara mengalami kerugian, karena masyarakat telah memiliki hak gugat sendiri. Fachrudin Djaya kemudian menambahkan jika Pemerintah hanya dapat mengajukan gugatan apabila pencemaran/perusakan terjadi di luar hak milik privat." ${ }^{6}$

Dari forum RDPU tersebut, dikemukakan dua dasar pemerintah mengajukan gugatan atas kerusakan/pencemaran lingkungan, yakni kerugian negara dan kerugian lingkungan. Sayangnya, tidak ditemukan penjelasan lebih lanjut terkait masing-masing gagasan tersebut.

Pada tataran implementasinya, pemerintah melalui Kementerian Lingkungan Hidup (dan Kehutanan) tercatat pernah menggunakan beberapa landasan doktriner yang berbeda-beda dalam surat gugatannya atas kerusakan/pencemaran lingkungan hidup, yaitu gugatan pemerintah sebagai wali lingkungan hidup dan gugatan pemerintah atas dasar tanggung jawab negara. Penafsiranpenafsiran tersebut akan dijelaskan lebih lanjut pada diskusi di bawah ini.

secara sendiri-sendiri atau bersama-sama, karena kewenangan daerah berdasarkan pelimpahan dari pemerintah pusat. (Bab IV Pedoman Penanganan Perkara Perdata Lingkungan, Keputusan Ketua MA No. 36/KMA/SK/II/2013).

${ }^{6}$ Henri Subagiyo (ed), Anotasi Undang-Undang Nomor 32 Tahun 2009 tentang Perlindungan dan Pengelolaan Lingkungan Hidup, ndonesian Center for Environmental Law (ICEL), Jakarta: 2014, hlm. 214-2015. 
Landasan Doktriner Hak Gugat Pemerintah Terhadap Kerugian Lingkungan Hidup di Indonesia

\section{Dalil Kerugian Negara}

Pada praktiknya, meskipun mengutip asas tanggung jawab negara sebagai alas kedudukannya sebagai penggugat, pemerintah Indonesia (KLHK) justru diindikasikan mengajukan gugatannya atas dasar karena negara telah mengalami kerugian, baik materiil maupun immateriil. Indikasi tersebut tidak semata didasarkan pada fakta bahwa usul pemerintah menggugat karena kerugian negara memang dibahas dalam RDPU Rancangan UU No. 32/2009, tetapi pula pada formulasi ganti rugi/kompensasi yang dituntutkan oleh pemerintah (KLHK) dalam gugatannya.

Di antara kerugian materiil yang didalilkan oleh KLHK adalah "kerugian ekosistem", yang atas timbulnya kerugian tersebut KLHK menuntut ganti rugi atau pembayaran kompensasi dalam jumlah uang tertentu kepada tergugat (pihak pencemar/perusak). ${ }^{7}$ Ganti rugi/kompensasi tersebut merupakan penerimaan negara sehingga pembayarannya disetorkan kepada kas negara. ${ }^{8}$ Menurut keterangan para ahli yang kerap ditunjuk oleh KLHK untuk melakukan perhitungan nilai kerugian lingkungan hidup dalam berbagai peristiwa kerusakan hutan dan lahan yang ditangani oleh KLHK, Prof. Bambang Hero Saharjo dan Dr. Basuki Wasis, uang ganti rugi/kompensasi atas kerugian ekosistem tidak digunakan untuk pemulihan lingkungan hidup yang mengalami kerusakan/tercemar, kegiatan pemulihan dilakukan dengan jumlah biaya pemulihan yang dibayarkan oleh tergugat. ${ }^{9}$

Paradigma berpikir bahwa hak gugat pemerintah didasarkan pada anggapan bahwa negara mengalami kerugian, pada kenyataannya menghadapi sejumlah persoalan. Pertama, sebagaimana telah ditegaskan oleh Mahkamah Konstitusi dalam putusannya, negara bukanlah pemilik sumber daya yang bukan milik privat (sungai, hutan lindung, pantai, laut, hewan-hewan di alam liar), melainkan masyarakat Indonesia secara kolektif memilikinya. ${ }^{10}$ Dalil "dikuasai oleh negara" sebagaimana dalam Pasal 33 ayat (3) UUD NRI Tahun 1945, yang dijadikan sebagai landasan kedudukan pemerintah sebagai penggugat dalam sengketa lingkungan di Indonesia, ${ }^{11}$ tidak dapat dimaknai sebagai bukti bahwa pemerintah mempunyai hak kepemilikan atas lingkungan yang bukan milik privat sehingga memungkinkan bagi negara untuk berhak menerima kompensasi atas kerugian

\footnotetext{
7 Terkait dengan kerugian lingkungan hidup, KLHK dalam gugatannya menuntut pihak perusak/pencemar untuk: i) membayar ganti rugi atas kerugian ekosistem; dan/atau iii) penggantian biaya pemulihan lingkungan hidup atau meminta perusak/pencemar untuk melakukan pemulihan terhadap lingkungan hidup yang rusak/tercemar akibat kegiatan/usaha yang dilakukannya. Belakangan, KLHK telah pula mengajukan penggantian biaya pelaksanaan Penyelesaian Sengketa Lingkungan Hidup, yang meliputi: biaya verifikasi lapangan, analisa laboratorium, ahli dan pengawasan pelaksanaan pembayaran kerugian lingkungan hidup. (Lihat: Putusan Pengadilan Negeri Kuala Kapuas Kelas II No. 51/Pdt.G/LH/2018/PN.KIk, hlm. 37-46; Putusan Pengadilan Negeri Jambi No. 107/Pdt.G/LH/2019/PN.Jmb, hlm. 11-24; Putusan Pengadilan Negeri Palembang Kelas IA No. 234/Pdt.G/LH/2016/PN.Plg, hlm. 11-17).

8 Pasal 8 Peraturan Menteri Lingkungan Hidup Nomor 7 Tahun 2014 tentang Kerugian Lingkungan Hidup Akibat Pencemaran dan/atau Kerusakan Lingkungan Hidup.

9 Keterangan dinyatakan oleh Bambang Hero Saharjo dalam wawancara dengan penulis yang dilakukan pada tanggal 8 November 2019. Sementara itu, Basuki Wasis melalui surat elektronik menjawab pertanyaan penulis pada tanggal 12 Oktober 2019.

${ }^{10}$ Lihat: Putusan Mahkamah Konstitusi Nomor 001-021-022/PUU-I/2003, hlm. 332-334.

${ }^{11}$ Lihat: Putusan Pengadilan Negeri Banjarmasin No. 125/Pdt.G/2016/PN.Bjm. hlm. 3; Putusan Pengadilan Negeri Palembang No. 24/Pdt.G/2015/PN.Plg. Hlm. 2; Putusan Pengadilan Negeri Jakarta Selatan No. 456/Pdt.G-LH/2016/PN.Jkt.Sel, hlm. 3; Putusan Pengadilan Negeri Meulaboh No. 12/PDT.G/2012/PN.MBO. HIm. 3-4; Putusan Pengadilan Negeri Jakarta Selatan No. 700/Pdt.G/2013/PN.Jkt.Sel, hlm. 2; Putusan Pengadilan Negeri Jambi No. 107/Pdt.G/LH/2019/PN.Jmb, hlm. 2-3.
} 
terhadap lingkungan dalam bentuk penerimaan negara. ${ }^{12}$ Mahkamah Konstitusi dalam putusannya telah menerangkan konsep "dikuasai oleh negara" adalah sesuatu yang lebih tinggi dari pemilikan. ${ }^{13}$ Kedua, dalil yang mendasarkan bahwa negara mengalami kerugian sehingga berhak mengajukan gugatan memang dikenali dalam tradisi common law di AS sebagai doktrin state's proprietary interest. ${ }^{14}$ Doktrin state's proprietary interest menyatakan bahwa public natural resources adalah properti kepunyaan negara, sehingga pencideraan berupa pencemaran/perusakkan terhadapnya dapat dinilai sebagai kepentingan (interest) oleh negara untuk mengajukan gugatan perdata di pengadilan untuk mendapatkan kompensasi dan negara (pemerintah) dapat menuntut dengan syarat yang sama dengan private litigant. ${ }^{15}$ Akan tetapi, ajaran state's proprietary interest yang demikian itu pada faktanya telah disimpangi dalam putusan Hughes v. Oklahoma yang menyebut bahwa "state's proprietary interest" sebagai "tidak lebih dari fiksi hukum abad ke-19", yang menunjukkan kepada warga negara tentang pentingnya kekuasaan negara untuk melindungi dan mengatur perihal eksploitasi suatu sumber daya yang penting. ${ }^{16}$

\section{Pemerintah Sebagai Wali Lingkungan Hidup}

Pada kasus Kementerian Lingkungan Hidup dan Kehutanan (KLHK) melawan PT. Arjuna Utama Sawit yang diputus pada tahun 2019, pemerintah (penggugat) mendalilkan bahwa hak gugat pemerintah atas kerugian lingkungan disandarkan pada teori tentang inanimated object, yang oleh pemerintah disebut dengan inanimated theory. Pemerintah menyatakan bahwa,

"Kedudukan Pemerintah dalam gugatan lingkungan hidup adalah seperti wali atau wakil dari lingkungan hidup sebagai suatu subyek hukum. Konsep tersebut diadopsi dari doktrin inanimated theory yang dikenal dalam hukum lingkungan, di mana lingkungan hidup dianggap

\footnotetext{
${ }^{12}$ Faktanya, dalil bahwa kerugian lingkungan merupakan bagian daripada kerugian negara tidak hanya dipahami dalam lingkup keperdataan, melainkan telah pula diterapkan pada ranah hukum pidana sebagaimana yang dilakukan oleh Jaksa Penuntut Umum Komisi Pemberantasan Korupsi (KPK) manakala mendakwa Gubernur Sulawesi Utara, Nur Alam, telah melakukan tindak pidana korupsi karena mengakibatkan kerugian negara yang berasal dari musnahnya atau berkurangnya ekologis/lingkungan. (Putusan Pengadilan Negeri Jakarta Pusat No. 123/Pid.Sus/2017/PN Jkt.Pst, hlm. 67-68).

${ }_{13}^{13}$ Putusan Mahkamah Konstitusi Nomor 001-021-022/PUU-I/2003, Loc.Cit.

${ }^{14}$ Doktrin state's proprietary interest diperkenalkan melalui putusan Mahkamah Agung dalam Geer v. Connecticut. Putusan ini membenarkan undang-undang yang melarang pengangkutan buruan liar yang ditangkap secara legal di wilayah Connecticut untuk dijual di luar Connecticut. Pengadilan menilai bahwa suatu negara bagian berdasarkan "kepemilikan" atas satwa liar yang masih di alam liar dapat melarang pengangkutan satwa liar tersebut untuk dijual di luar negara bagian tersebut. (Lihat: Geer v. Connecticut, 161 U.S. 519 (1896)).

Dalam putusan Wash. Dep. of Fisheries v. Gillette, Pengadilan Washington mengabulkan gugatan ganti rugi yang diajukan negara dengan menyatakan "the food fish of the state are the sole property of the people and that the State, acting for the people, is dealing with its own property, "over which its control is as absolute as that of any other owner over his property". Selain mengakui kepentingan negara atas ikannya, pengadilan menyatakan bahwa negara memegang haknya sebagai wali untuk kebaikan bersama. Oleh karena itu, negara dapat meminta ganti rugi untuk cedera pada objek kepercayaannya. Pengadilan juga mengatakan bahwa jika negara tidak menunaikan kewajibannya tersebut, tidak ada yang akan memiliki hak untuk memulihkan kerusakan. (Dep't of Fisheries v. Gillette, 27 Wn. App. 815, (Wash. Ct. App. 1980), hlm. 820-821). Lihat pula: State ex rel. Bacich v. Huse, 187 Wn. 75, (Wash. 1936), hlm. 79; Judd v. Bernard, 49 Wn. 2d 619, (Wash. 1956), hlm. 622; State ex Rel. Campbell v. Case, 182 Wn. 334, (Wash. 1935), hlm. 339.

${ }^{15}$ Seth Davis, "Federal Courts, Practice and Procedure: State Spending: The Private Rights of Public Governments", No. 1, Vol. 94, 2019, hlm. 2100.

${ }^{16}$ Hughes v. Oklahoma, 441 U.S. 332 (1976), hlm. 336.
} 
Landasan Doktriner Hak Gugat Pemerintah Terhadap Kerugian Lingkungan Hidup di Indonesia

sebagai subyek hukum yang tak berjiwa/tidak bernyawa, sehingga perlu ditunjuk wali yang dapat bertindak untuk melindungi dan mempertahankan hak-hak dan kepentingan hukumnya secara nyata."17

Penyataan permerintah yang menyebut bahwa dasar wewenangnya mengajukan gugatan karena mewakili kepentingan lingkungan dapat kita kaitkan dengan gagasan yang diusulkan oleh Stone dalam tulisannya "Should Trees Have Standing? - Toward Legal Rights for Natural Objects". Dalam artikel tersebut Stone menyebut bahwa,

"It is not inevitable, nor is it wise, that natural objects should have no rights to seek redress in their own behalf. It is no answer to say that streams and forests cannot have standing because streams and forests cannot speak. Corporations cannot speak either; nor can states, estates, infants, incompetents, municipalities or universities. Lawyers speak for them, as they customarily do for the ordinary citizen with legal problems. ...

On a parity of reasoning, we should have a system in which, when a friend of a natural object perceives it to be endangered, he can apply to a court for the creation of a guardianship." 18

Akan tetapi, pandangan tersebut menghadapi beberapa persoalan manakala diterapkan secara konsisten di Indonesia. Setidaknya ada dua kendala yang dihadapi. Pertama, dalam putusan kasus tersebut terjadi perbedaan pemaknaan antara pemerintah dan majelis hakim mengenai teori terkait inanimated object. Dalam pertimbangannya, majelis hakim melihat penggunaan teori tersebut sebagai pendukung kedudukan pemerintah sebagai pihak dalam mengajukan gugatan atas

\footnotetext{
${ }^{17}$ Putusan Pengadilan Negeri Palangkaraya No. 213/Pdt.G/LH/2018/PN.Plk, hlm. 3.

${ }^{18}$ Christopher D. Stone, "Should Trees Have Standing? - Toward Legal Rights for Natural Objects", Southern California Law Review, Vol. 45, 1972, hlm. 464

Gagasan Stone tersebut pada faktanya telah diterapkan di negara Ekuador. Dalam konstitusinya yang diamandemen pada tahun 2008 secara eksplisit dinyatakan bahwa lingkungan atau alam merupakan subyek yang mempunyai hak asasinya sendiri di samping hak asasi manusia yang wajib dijamin oleh undang-undang dasar. Ketentuan tersebut tercantum dalam Title // tentang "Rights", "Article of Rights Entitlement" sebagai berikut: "Persons and people have the fundamental rights guaranteed in this Constitution and in the International human rights instruments. Nature is subject to those rights given by this Constitution and Law." Selanjutnya, pada Article 71 disebutkan secara jelas bahwa, "Nature, or Pacha Mama, where life is reproduced and occurs, has the right to integral respect for its existence and for the maintenance and regeneration of its life cycles, structure, functions and evolutionary processes." (Jimly Asshiddiqie, Green Constitution: Nuansa Hijau Undang-Undang Dasar Negara Republik Indonesia Tahun 1945, Rajawali Pers, Jakarta: 2009, hlm. 73). Selain itu, pandangan yang demikian itu pernah diketengahkan di pengadilan AS, yakni dalam kasus Sierra Club v. Morton, di mana Hakim Douglas dalam dissenting opinion menyatakan bahwa,

"Inanimate objects are sometimes parties in litigation. A ship has a legal personality, a fiction found useful for maritime purposes. The corporation sole -- a creature of ecclesiastical law -- is an acceptable adversary and large fortunes ride on its cases. The ordinary corporation is a "person" for purposes of the adjudicatory processes, whether it represents proprietary, spiritual, aesthetic, or charitable causes.

So it should be as respects valleys, alpine meadows, rivers, lakes, estuaries, beaches, ridges, groves of trees, swampland, or even air that feels the destructive pressures of modern technology and modern life. The river, for example, is the living symbol of all the life it sustains or nourishes -- fish, aquatic insects, water ouzels, otter, fisher, deer, elk, bear, and all other animals, including man, who are dependent on it or who enjoy it for its sight, its sound, or its life. The river as plaintiff speaks for the ecological unit of life that is part of it. Those people who have a meaningful relation to that body of water -- whether it be a fisherman, a canoeist, a zoologist, or a logger -- must be able to speak for the values which the river represents and which are threatened with destruction." (Lihat: Sierra Club v. Morton, 405 U.S. $727(1972))$.
} 
kerugian lingkungan, bukan memberi alas/dasar bagi lingkungan sebagai subyek hukum yang kepentingannya dilanggar sebagaimana yang dikemukakan oleh penggugat. ${ }^{19}$ Berikut pertimbangan majelis hakim tersebut:

“Majelis hakim berpendapat Penggugat telah dapat membuktikan bahwa Pengggat adalah pihak yang berhak untuk mengajukan gugatan terhadap diri Tergugat karena sesuai doktrin inanimate theory [sic!] Penggugat dianggap sebagai subyek hukum yang ditunjuk sebagai wali/wakil (artificial person) yang dapat bertindak untuk melindungi dan mempertahankan hak-hak dan kepentingan hukumnya secara nyata berdasarkan Pasal 90 Undang-Undang Nomor 32 Tahun 2009 tentang Perlindungan dan Pengelolaan Lingkungan Hidup, Penggugat diberikan hak dan kewenangan untuk mengajukan gugatan ganti rugi, dan tindakan tertentu terhadap penanggung jawab usaha dan/atau kegiatan yang telah menyebabkan pencemaran dan/atau kerusakan lingkungan hidup, dan mengakibatkan kerugian lingkungan hidup. Lebih lanjut, kewenangan Penggugat tersebut, diatur dalam Undang-Undang Nomor 39 Tahun 2008 tentang Kementerian Negara juncto Peraturan Presiden Nomor 16 Tahun 2015 tentang Kementerian Lingkungan Hidup dan Kehutanan, serta Peraturan Menteri Lingkungan Hidup dan Kehutanan Nomor P.18/Menlhk-II/2015 tentang Organisasi dan Tata Kerja Kementerian Lingkungan Hidup dan Kehutanan yang menetapkan bahwa tugas pokok dan fungsi dalam penyelenggaran pemerintahan Negara di bidang lingkungan hidup dan kehutanan berada di bawah Kementerian Lingkungan Hidup dan Kehutanan. Dengan demikian, Penggugat adalah pihak yang memiliki kepentingan maupun kewenangan hukum sesuai ketentuan peraturan perundang-undangan untuk mengajukan gugatan atas nama Pemerintah." ${ }^{20}$

Kedua, dalam konstitusi Indonesia, lingkungan hidup tidak dipandang memiliki kepentingan hukum sendiri (sebagai subyek hukum), tetapi merupakan bagian dari hak dasar warga negara yang wajib dipenuhi oleh negara, yakni "mendapatkan lingkungan hidup yang baik dan sehat". ${ }^{21}$ Santosa menempatkan komitmen konstitusional Indonesia tersebut dalam kategori sedang, yakni memberikan pengakuan tentang subjective rights (diatur dalam Pasal 28H UUD NRI Tahun 1945) tanpa mengakui secara spesifik duty of the state di bidang pengelolaan lingkungan. Meskipun demikian, terdapat muatan tentang pola dan arah pembangunan berkelanjutan (diatur pada Pasal

\footnotetext{
${ }^{19}$ Putusan Pengadilan Negeri Palangkaraya No. 213/Pdt.G/LH/2018/PN.Plk, hlm. 196-197.

${ }^{20}$ Putusan Pengadilan Negeri Palangkaraya, Ibid.

${ }^{21}$ Pasal 28H ayat (1) UUD NRI Tahun 1945.
} 
Landasan Doktriner Hak Gugat Pemerintah Terhadap Kerugian Lingkungan Hidup di Indonesia

33 ayat (4) UUD NRI Tahun 1945), walaupun tidak ditempatkan dalam pasal-pasal khusus, melainkan ditumpangkan atau dicampur dengan hak-hak fundamental lainnya. ${ }^{22}$

\section{Konsekuensi dari Tanggung Jawab Negara}

Dalam putusan-putusan pengadilan lainnya, didapati bahwa umumnya pemerintah (KLHK) merujuk pada "asas tanggung jawab negara" untuk mendukung kedudukan hukumnya dalam mengajukan gugatan atas kerusakan dan/atau pencemaran lingkungan. Pemerintah berdalih bahwa gugatan dapat diajukan oleh pemerintah terhadap pihak yang mencederai pelaksanaan tanggung jawab negara berkenaan dengan lingkungan hidup. Dalil demikian itu dinyatakan oleh KLHK dalam gugatannya, misalnya dalam kasus KLHK melawan PT. Palmina Utama sebagai berikut:

“... negara bertanggung jawab menjamin pemanfaatan sumber daya alam untuk memberikan manfaat sebesar - besarnya bagi kesejahteraan dan hidup rakyat baik generasi masa kini maupun masa depan, menjamin hak warga negara untuk memperoleh lingkungan hidup yang baik dan sehat serta untuk mencegah perusakan dan atau pencemaran lingkungan hidup dari kegiatan pemanfaatan sumber daya alam. Sebagai konsekuensi pelaksanaan asas tanggung jawab tersebut pemerintah dapat mengambil tindakan hukum terhadap pelaku usaha yang dianggap telah merusak atau mencemari lingkungan hidup sehingga menimbulkan kerugian lingkungan hidup;" ${ }^{23}$ (garis bawah oleh penulis)

Selanjutnya, pemerintah (KLHK) mengaitkan konsekuensi pelaksanaan tanggung jawab negara dengan ketentuan Pasal 90 ayat (1) UU No. 32/2009. Instansi pemerintah dan pemerintah daerah yang bertanggung jawab di bidang lingkungan hidup, menurut pasal tersebut, berwenang mengajukan gugatan ganti rugi dan tindakan tertentu terhadap usaha dan/atau kegiatan yang menyebabkan pencemaran dan/atau kerusakan lingkungan hidup yang mengakibatkan kerugian

\footnotetext{
22 Santosa mengelompokkan komitmen atas tingkatan komitmen negara terhadap perlindungan lingkungan pada konstitusi-konstitusi negara di dunia menjadi lima kategori, antara lain: i) komitmen tertinggi; b) komitmen tinggi; c) komitmen memadai; d) komitmen sedang; dan e) komitmen rendah.

Kategori pertama, adalah konstitusi yang memberikan pengakuan yang lengkap atas hak hukum untuk alam (the right for the nature), yaitu hak alam sebagai manifestasi dari paham ekosentrisme, hak-hak subjektif, kewajiban negara, serta arah pembangunan. Kategori kedua hampir sama dengan kategori pertama selain tidak diakuinya the right for the nature dikarenakan pendekatan kategori kedua masih antroposentris. Kategori ketiga mengakui hak-hak subjektif dan kewajiban negara dalam pasal-pasal khusus dan tersendiri (tidak dicampur aduk dengan hak-hak lain). Kategori keempat memberikan pengakuan hak subjektif tanpa mengakui kewajiban negara, namun memberikan arah pada pola pembangunan nasional. Hak subjektif dan arah pembangunan tidak diatur secara spesifik, tetapi digabung dengan hak-hak lainnya. Terakhir, pada kategori kelima, konstitusi sama sekali tidak mengakui norma hukum lingkungan (hak subjektif maupun kewajiban negara), maupun pengakuan pola dan arah pembangunan berkelanjutan. (Mas Achmad Santosa, Alam pun Butuh Hukum dan Keadilan, Prima Pustaka, Jakarta: 2016, hlm. 22).

${ }^{23}$ Putusan Pengadilan Negeri Banjarmasin No. 125/Pdt.G/2016/PN.Bjm, hlm. 3.

Lihat pula: Putusan Pengadilan Negeri Palembang No. 24/Pdt.G/2015/PN.Plg, hlm. 2; Putusan Pengadilan Negeri Jakarta Selatan No. 456/Pdt.G-LH/2016/PN.Jkt.Sel, hlm. 3; Putusan Pengadilan Negeri Meulaboh No. 12/PDT.G/2012/PN.MBO, hlm. 3-4; Putusan Pengadilan Negeri Jakarta Selatan No. 700/Pdt.G/2013/PN.Jkt.Sel, hlm. 2; Putusan Pengadilan Negeri Jambi No. 107/Pdt.G/LH/2019/PN.Jmb, hlm. 2-3; Putusan Pengadilan Negeri Kuala Kapuas Kelas II No. 51/Pdt.G/LH/2018/PN.KIk, hIm. 2; Putusan Pengadilan Negeri Palembang Kelas IA No. 234/Pdt.G/LH/2016/PN.Plg, hlm. 3; Putusan Pengadilan Negeri Jambi No. 139/Pdt.GLH/2016/PN.Jmb, hlm. 2-3; Putusan Pengadilan Negeri Jakarta Utara No. 735/Pdt.G-LH/2018/PN.Jkt.Utr, hlm. 3-5).
} 
lingkungan hidup. Dengan konstruksi berpikir yang demikian itu KLHK menunjukkan bahwa pemerintah memiliki kualitas (standi in judicio) sebagai penggugat atas kerusakan/pencemaran lingkungan hidup.

Dalil pemerintah tersebut pada kenyataannya terus diterima dan tidak pernah dipermasalahkan oleh pengadilan. Akan tetapi, ditinjau dari perspektif teoretis konstruksi dasar hak gugat pemerintah tersebut menyimpan sejumlah persoalan. Pertama, asas tanggung jawab negara yang dirujuk oleh pemerintah dalam gugatannya berbeda dari prinsip tanggung jawab negara yang dipahami dalam hukum lingkungan internasional - "the responsibility of states not to cause damage to the environment of other states or to areas beyond national jurisdiction". ${ }^{24}$ Asas tanggung jawab negara yang didalilkan oleh pemerintah Indonesia adalah yang dimuat pada Pasal 2 huruf a UU No. 32/2009, yang diartikan sebagai berikut:

"Yang dimaksud dengan "asas tanggung jawab negara" adalah:

a. negara menjamin pemanfaatan sumber daya alam akan memberikan manfaat yang sebesar-besarnya bagi kesejahteraan dan mutu hidup rakyat, baik generasi masa kini maupun generasi masa depan.

b. negara menjamin hak warga negara atas lingkungan hidup yang baik dan sehat.

c. negara mencegah dilakukannya kegiatan pemanfaatan sumber daya alam yang menimbulkan pencemaran dan/atau kerusakan lingkungan hidup." ${ }^{25}$

Kedua, tulisan ini melihat bahwa tiga lingkup tanggung jawab negara dalam rezim UU No. 32/2009 merujuk pada dua ketentuan konstitusional yang berbeda. Tanggung jawab negara pada poin a merujuk kepada Pasal 33 ayat (3) UUD NRI Tahun 1945 yang mengamanatkan bahwa, "Bumi dan air dan kekayaan alam yang terkandung di dalamnya dikuasai oleh negara dan dipergunakan untuk sebesar-besar kemakmuran rakyat". Sementara itu, tanggung jawab negara pada poin b dan c berkaitan dengan Pasal 28H ayat (1) UUD NRI Tahun 1945 yang berbunyi, "Setiap orang berhak hidup sejahtera lahir dan batin, bertempat tinggal, dan mendapatkan lingkungan hidup yang baik dan sehat serta berhak memperoleh pelayanan kesehatan." Pengutipan secara eksplisit terhadap

\footnotetext{
${ }^{24}$ Phillipe Sands, Principles of International Environmental Law, Cambridge University Press, United Kingdom: 2003, hlm. 235-246. Prinsip tanggung jawab negara yang dipahami dalam hukum lingkungan internasional senyatanya bersesuaian dengan asas tanggung jawab yang dimuat dalam Pasal 3 UU No. 23/1997, yang dalam Penjelasannya dinyatakan, “Berdasarkan asas tanggung jawab negara, di satu sisi, negara menjamin bahwa pemanfaatan sumber daya alam akan memberikan manfaat yang sebesar-besarnya bagi kesejahteraan dan mut [sic!] hidup rakyat, baik generasi masa kini maupun generasi masa depan. Di lain sisi, negara mencegah dilakukannya kegiatan pemanfaatan sumber daya alam dalam wilayah yurisdiksinya yang menimbulkan kerugian terhadap wilayah yurisdiksi negara lain, serta melindungi negara terhadap dampak kegiatan di luar wilayah negara."

${ }^{25}$ Penjelasan Pasal 2 huruf a UU No. 32/2009.
} 
Landasan Doktriner Hak Gugat Pemerintah Terhadap Kerugian Lingkungan Hidup di Indonesia

ketentuan kontitusi tersebut tercatat dilakukan oleh pemerintah dalam kasus KLHK melawan PT. National Sago Prima ${ }^{26}$ dan KLHK melawan PT. Merbau Pelelawan Lestari. ${ }^{27}$

Persoalannya adalah bahwa Pasal 33 ayat (3) dan Pasal 28H ayat (1) UUD NRI Tahun 1945 berangkat dari landasan doktriner yang berbeda. Titik fokus Pasal 33 ayat (3) UUD NRI Tahun 1945 adalah pada penguasaan negara atas sumber-sumber daya alam yang secara kolektif dimiliki oleh bangsa untuk sebesar-besarnya kemakmuran rakyat. Hal ini tercermin dalam pandangan Mahkamah Konstitusi berikut ini:

“... perkataan "dikuasai oleh negara" haruslah diartikan mencakup makna penguasaan oleh negara dalam arti luas yang bersumber dan berasal dari konsepsi kedaulatan rakyat Indonesia atas segala sumber kekayaan "bumi dan air dan kekayaan alam yang terkandung di dalamnya", termasuk pula di dalamnya pengertian kepemilikan publik oleh kolektivitas rakyat atas sumber-sumber kekayaan dimaksud. Rakyat secara kolektif itu dikonstruksikan oleh UUD 1945 memberikan mandat kepada negara untuk mengadakan kebijakan (beleid) dan tindakan pengurusan (bestuursdaad), pengaturan (regelendaad), pengelolaan (beheersdaad) dan pengawasan (toezichthoudensdaad) untuk tujuan sebesar-besarnya kemakmuran rakyat." 28

Siahaan menyatakan bahwa negara sebagai pemegang kekuasaan atas "alam" sebagaimana tercantum dalam Pasal 33 UUD NRI Tahun 1945 harus senantiasa berkewajiban dan bertanggung jawab, bukan hanya dalam arti responsibilitas, tetapi juga dalam arti liabilitas (tanggung jawab hukum atas kerugian-kerugian yang diderita korban). Kewajiban dan tanggung jawab negara dalam arti responsibilitas berkaitan dengan kewajiban dan tanggung jawab negara secara moral, politik, dan relegius atas kerusakan dan/atau pencemaran lingkungan, sedangkan kewajiban dan tanggung jawab negara dalam arti liabilitas lebih mengarah pada kewajiban dan tanggung jawab hukum (proses hukum).

Disandingkan dengan doktrin yang diaplikasikan dalam tradisi common law, konsep tanggung jawab negara dalam Pasal 33 ayat (3) UUD NRI Tahun 1945 cenderung memiliki kesamaan dengan doktrin public trust. Doktrin public trust merupakan doktrin common law yang berakar pada hukum Romawi, yang menetapkan bahwa udara, sungai, laut, dan pantai sebagai barang/properti publik (common to all). ${ }^{29}$ Bangsa Romawi mengenal properti demikian itu sebagai res communes yang dapat

\footnotetext{
${ }^{26}$ Putusan Pengadilan Negeri Jakarta Selatan No. 591/Pdt.G-LH/2015/PN.Jkt.Sel, hlm. 2.

27 Putusan Pengadilan Negeri Pekanbaru No. 157/Pdt.G/2013/PN.Pbr, hlm. 2-3.

${ }_{28}$ Putusan Mahkamah Konstitusi Nomor 001-021-022/PUU-I/2003, hlm. 334.

${ }^{29}$ Edward H.P. Brans, Liability for Damage to Public Natural Resources: Standing, Damage and Damage Assessment, Kluwer Law International, The Hague: 2001, hlm. 50.
} 
dinikmati dan digunakan oleh semua orang namun tidak dapat secara eksklusif dan sepenuhnya dimiliki oleh perorangan. ${ }^{30}$

Seperti banyak hukum umum Amerika lainnya, asal usul doktrin public trust Amerika adalah Inggris. Dalam common law Inggris, properti yang terkategori sebagai jus publicum/res communes dipegang oleh Raja in trust untuk rakyatnya. Properti tersebut utamanya terdiri dari perairan pantai dan sungai-sungai yang terkena dampak pasang surut air pasang, yang mana penting bagi masyarakat sebagai sarana navigasi dan perdagangan serta sebagai sumber makanan. ${ }^{31}$ Ketentuan doktrin tersebut tetap diberlakukan setelah Revolusi Amerika sebagaimana dimuat dalam putusan Arnold v. Mundy dan Martin v. Waddell. Hakim pada kedua kasus tersebut menyatakan bahwa hakhak yang dulunya dimiliki oleh kerajaan Inggris sekarang berada di tangan rakyat, diwakili oleh negara sebagai penguasa. ${ }^{32}$

Pada tahun 1970, cakupan doktrin public trust berkembang melewati batas tradisionalnya, dari yang semula "a doctrine of public rights in waterways and tidal lands" kepada "a doctrine protecting natural resources". Pergeseran tersebut dipengaruhi oleh pandangan Sax yang mengusulkan bahwa beberapa sumber daya alam, seperti lautan dan wilayah peraian (bodies of water) lainnya, garis pantai, udara, dan bagian tanah, diperlakukan oleh pengadilan sebagai "public trust" dan warga negara memiliki hak untuk menuntut agar melindungi public trust tersebut dari pemerintah, bisnis, dan individu yang mungkin mengancam mereka. ${ }^{33}$

Di bawah doktrin public trust, pemerintah bertindak sebagai wali (trustee) untuk sumber daya alam tertentu dan memiliki kewajiban untuk melindungi dan melestarikan sumber daya yang masuk dalam perwaliannya untuk kepentingan masyarakat umum. ${ }^{34}$ Menjadi bagian dari kewajibannya pula

\footnotetext{
${ }^{30}$ Edward H.P. Brans, Ibid, hlm. 36-37.

Dalam hukum Romawi dikenal 4 kategori lain dari "things" yang merupakan kepemilikan non-eksklusif atau incapable of ownership selain res communes. Mereka adalah: i) Res universitatis adalah benda-benda milik badan hukum, bukan milik perorangan seperti teater, lapangan pacuan kuda, dan tempat-tempat serupa lainnya yang menjadi milik seluruh kota." Konsep res universitatis adalah analogi Romawi yang paling dekat dengan kepemilikan modern oleh negara atau entitas negara; ii) Res sacrae atau religiosae, merupakan yang ditahbiskan oleh Paus sebagai bangunan suci dan persembahan yang didedikasikan untuk melayani Tuhan dan dilarang oleh konstitusi untuk dijual atau digadaikan. Dinding dan gerbang kota juga harus dilindungi dan disebut res sanctae; iii) Res publicae adalah bendabenda yang dimiliki umum untuk semua orang, seperti sungai dan pelabuhan. Konsep res communes dan res publicae sebenarnya sangat mirip. Res publicae merupakan properti publik seperti teater, tempat pasar, sungai, pelabuhan, dan lain-lain. Sebaliknya, res communes omnium tidak dianggap sebagai milik rakyat Romawi meskipun penggunaannya dapat diakses oleh semua warga negara; dan iv) Res nullius adalah hal-hal yang bukan milik siapa pun, baik karena mereka tidak disetujui oleh siapa pun, seperti tanah yang tidak dihuni atau hewan liar, atau hal-hal yang mirip dengan res sacraeor res religiosae. (Daniel R. Coquillette, "Mosses from an Old Manse: Another Look at Some Historic Property Cases About the Environment", Cornell Law Review, No. 5, Vol. 64, 1979, hlm. 801).

${ }^{31}$ Michael C. Blumm dan Aurora Paulsen, "The Public Trust in Wildlfe", Utah Law Review, No. 6, 2013, hlm. 1442.

32 Michael C. Blumm dan Aurora Paulsen, Ibid., hlm. 1444-1445.

${ }^{33}$ George P. Smith dan David M. Steenburg, "Environmental Hedonism or, Securing the Environment through the Common Law", William and Mary Environmental Law and Policy Review, No. 1, Vol. 40, 2015, hlm. 100.

${ }^{34}$ Peran negara sebagai wali untuk melindungi dan menjaga sumber daya alam tertentu dideskripsikan dalam kasus Illinois Central Railroad v. Illinois, di mana pengadilan memutuskan bahwa perairan untuk pelayaran (navigable waters) Danau Michigan yang dikuasai oleh Negara Bagian Illionis adalah suatu hak milik yang dipegang dengan kepercayaan rakyat bahwa mereka dapat menikmati perairan pelayaran, melakukan perdagangan di atasnya, dan memiliki kebebasan untuk memancing dan terbebas dari halangan atau campur tangan pihak swasta. (Illinois Central Railroad v. Illinois, 146 U.S. 387. HIm. 452). Lihat pula: Commonwealth of Puerto Rico v. SS Zoe Colocotroni, 628 F.2d 652 (1st Cir. 1980), hlm. 671.

Sementara itu, dalam State of New Jersey v. Jersey Central Power \& Light Co., pengadilan menyatakan bahwa "negara tidak hanya memiliki hak tetapi juga kewajiban fidusia yang tegas untuk memastikan bahwa hak-hak publik terhadap lingkungan laut yang layak
} 
Landasan Doktriner Hak Gugat Pemerintah Terhadap Kerugian Lingkungan Hidup di Indonesia

untuk memastikan hak-hak para beneficiary terlindungi, sehingga karenanya pemerintah dibolehkan menuntut kompensasi untuk setiap kerugian terhadap trust corpus. ${ }^{35}$

Sementara itu, ketentuan Pasal 28H ayat (1) UUD NRI Tahun 1945 lebih menitikberatkan pada pemenuhan hak masyarakat untuk mendapatkan lingkungan hidup yang baik dan sehat sebagai bagian dari pemenuhan terhadap kesejahteraannya. Santosa bahkan menegaskan bahwa dimuatnya Pasal $28 \mathrm{H}$ ayat (1) dalam konstitusi Indonesia menandakan pengakuan negara atas hak subyektif dan kewajiban negara dalam pengelolaan dan perlindungan lingkungan. ${ }^{36}$

Dalam konteks tradisi common law, hak gugat pemerintah yang didasarkan pada ketentuan Pasal 28H ayat (1) UUD NRI Tahun 1945 lebih dekat kepada doktrin parens patriae. Istilah "parens patriae" merupakan bahasa Latin, yang berarti "father of his country". Parens patriae pada mulanya adalah doktrin yang memberi kedudukan bagi Raja untuk melindungi rakyatnya yang tidak dapat melindungi diri mereka sendiri karena idiot atau gila. ${ }^{37}$

Dalam perkembangannya, di bawah doktrin ini negara dibolehkan untuk mengajukan gugatan atas biaya atau kerusakan yang timbul karena perilaku yang mengancam kesehatan, keselamatan, dan kesejahteraan warga negara, termasuk berkaitan dengan pencemaran/kerusakan lingkungan hidup. $^{38}$ Kepentingan negara yang demikian itu kemudian dikenali sebagai "quasi-sovereign interests". Pengadilan di AS tidak pernah secara spesifik mendefinisikan apa saja yang terkategori sebagai quasi-sovereign interests. ${ }^{39}$ Namun, quasi-sovereign interests dipahami sebagai kepentingan langsung dan independen dari negara, dan bukan hanya upaya oleh negara untuk memulihkannya demi kepentingan individu, ${ }^{40}$ dan berbeda dari kepentingan negara yang lain, seperti sovereign interest dan state's proprietary interest sebagaimana dinyatakan oleh Kanner sebagai berikut:

"A state's interests that may suffer damages can be sovereign, quasi-sovereign, or proprietary. As explained more fully below, the state's sovereign interest is its interest in seeing that its laws are obeyed and enforced, and that the health and well-being, both physical and economic, of its residents is protected. Behavior that violates criminal laws, civil laws, or other regulatory

terlindungi, dan untuk mencari kompensasi atas pengurangan dalam trust corpus tersebut." (State v. Jersey Central Power Light Co., 125 N.J. Super. 97, 103 (N.J. Super. App. Div. 1973)).

${ }^{35}$ Kevin T. Grady, "State Actions for Damage to Non-Commercial Living Natural Resources", Boston College Environmental Affairs Law Review, No. 2, Vol. 9, 1980, hlm. 409.

${ }^{36}$ Mas Achmad Santosa, Alam pun Butuh Hukum dan Keadilan, Loc. Cit.

${ }^{37}$ Thomas H. Koenig dan Michael L. Rustad, "Reconceptualizing the BP Oil Spill as Parens Patriae Products Liability", Houston Law Review, No. 2, Vol. 49, 2012, hlm. 309.

${ }^{38}$ Allan Kanner, "The Public Trust Doctrine, Parens Patriae, and the Attorney General as the Guardian of the State' s Natural Resources", Duke Environmental Law and Policy Forum, No. 57, Vol. 16, 2005, hlm. 100-101.

Lihat: Maryland v. Amerada Hess Corp., 350 F. Supp. 1060 (D. Md. 1972); California v. S.S. Bournemouth, 307 F. Supp. 922 and 318 F. Supp. 839 (C.D. Cal. 1970); Maine v. M/V Tamano, 357 F. Supp. 1097, 1102 (D. Me. 1973).

${ }^{39}$ Pengadilan dalam Snapp \& Son, Inc. v. Puerto Rico ex rel. Barez menyatakan bahwa "[...] (quasi-sovereign interests) consist of a series of interests that the State has in the welfare of its population". Definisi yang luas tersebut disadari sepenuhnya akan membawa ketidakjelasan sehingga pengadilan menyerahkan perinciannya berdasarkan pada tiap-tiap kasus yang terjadi. (Snapp \& Son, Inc. $v$. Puerto Rico ex rel. Barez, 458 U.S. 592 (1982), hlm. 602).

${ }^{40}$ Allan Kanner, Op.Cit., hlm. 100. 
provisions compromises the very sovereignty of the state and can be subjective of a civil action brought in the state's name. But the state does more than merely enforce its laws-a state's quasi-sovereign interests include its interest in its citizens' health, safety, and welfare as well as in a healthful environment. A state's proprietary interests are those that the state asserts on its own behalf as might any other legal entity." ${ }^{\prime 1}$

Pertanyaan yang kemudian muncul adalah di antara dua doktrin tersebut, manakah yang paling dapat menjelaskan dasar hak gugat pemerintah atas kerusakan/pencemaran lingkungan hidup berdasarkan pada praktek yang diterapkan di Indonesia dewasa ini? Jawaban atas pertanyaan tersebut amat tergantung pada konstruksi Pasal 90 ayat (1) UU No. 32/2009 sebagai norma utama yang saat ini didalilkan oleh pemerintah dalam mengajukan gugatannya. Wibisana menilai bahwa rumusan hak gugat pemerintah yang dimuat oleh Pasal 90 ayat (1) UU No. 32/2009 memiliki kerangka berpikir yang dekat dengan doktrin public trust karena hak gugat pemerintah muncul untuk kerugian pada lingkungan yang bukan hak milik privat, meskipun pada prakteknya dapat pula diterapkan pada sumber daya yang menjadi milik seseorang (privately owned resources). ${ }^{42}$

\section{Hak Gugat Pemerintah dan Pemulihan Lingkungan Hidup}

Berangkat dari dasar teoretis yang telah dipaparkan pada bagian sebelumnya, dapat dipahami bahwa secara konstitusional hak gugat pemerintah di Indonesia muncul dari konsekuensi pelaksanaan tanggung jawab negara untuk memastikan lingkungan yang baik dan sehat bagi kesejahteraan warganya, atau dalam konteks Pasal 90 ayat (2) UU No.32/2009 hak gugat pemerintah muncul dari tanggung jawab pemerintah atas kerugian/kerusakan lingkungan hidup yang bukan milik privat. Keduanya secara berturut-turut memiliki kemiripan dengan maksud doktrin parens patriae dan doktrin public trust dalam tradisi common law.

Baik doktrin parens patriae maupun doktrin public trust mengharuskan bahwa ganti rugi/kompensasi yang diperoleh pemerintah melalui gugatan yang diajukannya harus digunakan untuk memulihkan lingkungan hidup yang rusak/tercemar kepada kondisinya semula sebagaimana sebelum terjadi insiden pencemaran/kerusakan atau setidak-tidaknya mendekati kondisi dasar tersebut. Dengan demikian kerugian yang dirasakan oleh publik karena rusak/tercemarnya lingkungan hidup milik bersama dapat dipulihkan. Hal tersebut adalah konsekuensi hukum dari gugatan yang diajukan oleh pemerintah sebagai wali atau trustee yang bertindak atas kepentingan publik selaku beneficiary.

\footnotetext{
${ }^{41}$ Allan Kanner, lbid., hlm. 101.

${ }^{42}$ Andri G. Wibisana, Penegakan Hukum Lingkungan Melalui Pertanggungjawaban Perdata, BP-FHUI, Depok: 2017, hlm. $24-25$.
} 
Konsekuensi gugatan pemerintah sebagaimana menurut doktrin parens patriae maupun doktrin public trust tersebut semestinya berlaku pula pada gugatan pemerintah di Indonesia. Bagaimanapun tujuan utama gugatan pemerintah belumlah tercapai bila hanya sampai dengan pembayaran ganti rugi/kompensasi atas kerugian lingkungan oleh pihak perusak/pencemar. Tujuan tersebut akan tercapai secara utuh jika telah terpulihkannya situs sumber daya milik publik yang rusak/tercemar atau telah kembali fungsi-fungsi ekologisnya ke kondisi dasarnya sebagaimana sebelum terjadi pencemaran/kerusakan. Konsekuensinya, setiap kompensasi yang diperoleh dari gugatan pemerintah ini pada dasarnya tidak boleh dianggap sekedar pendapatan negara. Harus dipastikan bahwa kompensasi tersebut akan benar-bendar digunakan untuk pemulihan lingkungan yang diklaim oleh pemerintah telah rusak. Hanya dengan jalan ini kepentingan publik atas lingkungan hidup yang baik dan sehat dapat dijamin kembali.

\section{PENUTUP}

Gugatan pemerintah atas kerusakan dan/atau pencemaran lingkungan hidup di Indonesia diajukan berdasarkan pada beberapa landasan doktriner, antara lain: i) negara sebagai wali lingkungan hidup; ii) kerugian negara; dan iii) konsekuensi dari tanggung jawab negara terkait lingkungan hidup. Baik gugatan yang diajukan dengan interest pemerintah adalah wali bagi lingkungan hidup maupun gugatan pemerintah berdasarkan kerugian negara mengalami persoalan konstitusionalitas. Selain itu, keduanya dipandang tidak relevan dengan perkembangan hak gugat lingkungan dalam tradisi common law.

Hak gugat pemerintah yang didasari oleh konsekuensi pelaksanaan tanggung jawab pemerintah adalah yang dipandang paling rasional dengan situasi yang dimiliki Indonesia. Asas tanggung jawab dalam rezim UU No. 32/2009 ditemukan merujuk pada dua ketentuan konstitusional yang berbeda, yakni Pasal 33 ayat (3) dan Pasal 28H ayat (1) UUD NRI Tahun 1945. Perbedaan landasan konstitusional tersebut berimplikasi pada perbedaan pendekatan dasar menggugat pemerintah.

Konsep tanggung jawab negara dalam Pasal 33 ayat (3) UUD NRI Tahun 1945 cenderung memiliki kesamaan dengan doktrin public trust, di mana pemerintah bertindak sebagai wali (trustee) untuk sumber daya alam tertentu dan memiliki kewajiban untuk melindungi dan melestarikan sumber daya yang masuk dalam perwaliannya untuk kepentingan masyarakat umum. Sedangkan asas tanggung jawab negara yang diturunkan dari Pasal 28H ayat (1) UUD NRI Tahun 1945 lebih menitikberatkan pada pemenuhan hak masyarakat untuk mendapatkan lingkungan hidup yang baik dan sehat sebagai bagian dari pemenuhan terhadap kesejahteraannya, singga lebih dekat kepada doktrin parens patriae. Melihat pada konstruksi Pasal 90 ayat (1) UU No. 32/2009 yang menjadi 
landasan utama gugatan pemerintah atas kerusakan/pencemaran lingkungan di Indonesia saat ini, hak gugat pemerintah yang condong kepada doktrin public trust dinilai sebagai yang paling dapat menjelaskan dasar hak gugat pemerintah atas kerusakan/pencemaran lingkungan hidup di Indonesia.

Berdasarkan doktrin public trust dan doktrin parens patriae, pemerintah berkewajiban menggugat setiap pihak yang telah menyebabkan pencemaran dan/atau kerusakan terhadap sumber daya tertentu yang dimiliki secara bersama oleh publik. Pemerintah selanjutnya wajib menggunakan ganti rugi/kompensasi yang diterimanya untuk memulihkan lingkungan hidup yang rusak/tercemar dan mengembalikan fungsi-fungsi ekologis yang hilang atau terganggu kepada kondisi dasarnya sebagaimana sebelum terjadi pencemaran/kerusakan. Dengan demikian, sudah semestinya jika hak gugat pemerintah muncul bersamaan dengan telah dilakukannya atau akan dilakukannya pemulihan lingkungan oleh pemerintah. Dari rangkaian argumen ini, muncul suatu kebutuhan untuk meneliti apakah sejauh ini gugatan pemerintah di Indonesia telah diterapkan sebagai bagian dari upaya untuk memastikan dilakukannya pemulihan atas lingkungan yang rusak.

\section{DAFTAR PUSTAKA}

\section{Buku}

Andri G. Wibisana, Penegakan Hukum Lingkungan Melalui Pertanggungjawaban Perdata, BP-FHUI, Depok: 2017.

Direktorat Jenderal Penegakan Hukum Lingkungan Hidup dan Kehutanan, Laporan Kinerja Tahun 2019, Setditjen Penegakan Hukum Lingkungan Hidup dan Kehutanan, Jakarta: 2020.

Edward H.P. Brans, Liability for Damage to Public Natural Resources: Standing, Damage and Damage Assessment, Kluwer Law International, The Hague: 2001.

Henri Subagiyo (ed), Anotasi Undang-Undang Nomor 32 Tahun 2009 tentang Perlindungan dan Pengelolaan Lingkungan Hidup, ndonesian Center for Environmental Law (ICEL), Jakarta: 2014. Jimly Asshiddiqie, Green Constitution: Nuansa Hijau Undang-Undang Dasar Negara Republik Indonesia Tahun 1945, Rajawali Pers, Jakarta: 2009.

Kementerian Lingkungan Hidup dan Kehutanan RI, Laporan Kinerja 2019, Biro Perencanaan Kementerian Lingkungan Hidup dan Kehutanan, Jakarta: 2020.

Mas Achmad Santosa, Alam pun Butuh Hukum dan Keadilan, Prima Pustaka, Jakarta: 2016.

Phillipe Sands, Principles of International Environmental Law, Cambridge University Press, United Kingdom: 2003. 


\section{Jurnal}

Allan Kanner, "The Public Trust Doctrine, Parens Patriae, and the Attorney General as the Guardian of the State's Natural Resources", Duke Environmental Law and Policy Forum, No. 57, Vol. 16, 2005.

Christopher D. Stone, "Should Trees Have Standing? - Toward Legal Rights for Natural Objects", Southern California Law Review, Vol. 45, 1972.

Daniel R. Coquillette, "Mosses from an Old Manse: Another Look at Some Historic Property Cases About the Environment", Cornell Law Review, No. 5, Vol. 64, 1979.

George P. Smith dan David M. Steenburg, "Environmental Hedonism or, Securing the Environment through the Common Law", William and Mary Environmental Law and Policy Review, No. 1, Vol. 40, 2015.

Kevin T. Grady, "State Actions for Damage to Non-Commercial Living Natural Resources", Boston College Environmental Affairs Law Review, No. 2, Vol. 9, 1980.

Lisa Moscati Hawkes, "Parens Patriae and the Union Carbide Case: The Disaster at Bhopal Continues", Cornell International Law Journal, No. 1, Vol. 21, 1988.

Michael C. Blumm dan Aurora Paulsen, "The Public Trust in Wildlfe", Utah Law Review, No. 6, 2013.

Seth Davis, "Federal Courts, Practice and Procedure: State Spending: The Private Rights of Public Governments", No. 1, Vol. 94, 2019.

Thomas H. Koenig dan Michael L. Rustad, "Reconceptualizing the BP Oil Spill as Parens Patriae Products Liability", Houston Law Review, No. 2, Vol. 49, 2012.

\section{Peraturan Perundang-Undangan}

Undang-Undang Dasar Negara Republik Indonesia Tahun 1945.

Undang-Undang Nomor 32 Tahun 2009 tentang Perlindungan dan Pengelolaan Lingkungan Hidup.

Undang-Undang Nomor 23 Tahun 1997 tentang Pengelolaan Lingkungan Hidup.

Peraturan Menteri Lingkungan Hidup Nomor 7 Tahun 2014 tentang Kerugian Lingkungan Hidup Akibat Pencemaran dan/atau Kerusakan Lingkungan Hidup.

Undang-Undang Nomor 4/1982 tentang Ketentuan-ketentuan Pokok Pengelolaan Lingkungan Hidup. Keputusan Ketua Mahkamah Agung Nomor 036/KMA/SK/II/2013 tentang Pemberlakuan Pedoman Penanganan Perkara Lingkungan Hidup.

CERCLA (Comprehensive Environmental Response, Compensation, and Liability Act).

OPA (Oil Pollution Act). 


\section{Putusan Pengadilan}

Putusan Mahkamah Konstitusi Nomor 001-021-022/PUU-I/2003 perihal Uji Materiil Undang-Undang Nomor 20 Tahun 2002 tentang Ketenagalistrikan terhadap UUD NRI Tahun 1945, tanggal 15 Desember 2004.

Putusan Pengadilan Negeri Palangkaraya Nomor 213/Pdt.G/LH/2018/PN.Plk perihal Kementerian Lingkungan Hidup dan Kehutanan melawan PT. Arjuna Utama Sawit, tanggal 21 Oktober 2019.

Putusan Pengadilan Negeri Palembang Nomor 24/Pdt.G/2015/PN.Plg perihal Kementerian Lingkungan Hidup dan Kehutanan melawan PT. Bumi Mekar Hijau, tanggal 30 Desember 2015. Putusan Pengadilan Negeri Jakarta Selatan Nomor 456/Pdt.G-LH/2016/PN.Jkt.Sel perihal Kementerian Lingkungan Hidup dan Kehutanan melawan PT. Waringin Agro Jaya, tanggal 7 Februari 2017.

Putusan Pengadilan Negeri Jakarta Selatan Nomor 700/Pdt.G/2013/PN.Jkt.Sel perihal Menteri Lingkungan Hidup melawan PT. Surya Panen Subur, tanggal 25 September 2014.

Putusan Pengadilan Negeri Meulaboh Nomor 12/PDT.G/2012/PN.MBO perihal Menteri Lingkungan Hidup melawan PT. Kallista Alam, tanggal 28 November 2013.

Putusan Pengadilan Negeri Banjarmasin Nomor 125/Pdt.G/2016/PN.Bjm perihal Kementerian Lingkungan Hidup dan Kehutanan melawan PT. Palmina Utama, tanggal 21 Februari 2018.

Putusan Pengadilan Negeri Jambi Nomor 107/Pdt.G/LH/2019/PN.Jmb perihal Kementerian Lingkungan Hidup dan Kehutanan melawan PT. Agro Tumbuh Gemilang Abadi, tanggal 13 April 2020.

Putusan Pengadilan Negeri Kuala Kapuas Kelas II No. 51/Pdt.G/LH/2018/PN.Klk perihal Kementerian Lingkungan Hidup dan Kehutanan melawan PT. Kalimantan Lestari Mandiri, tanggal 8 Mei 2019.

Putusan Pengadilan Negeri Palembang Kelas IA No. 234/Pdt.G/LH/2016/PN.Plg perihal Kementerian Lingkungan Hidup dan Kehutanan melawan PT. Waimusi Agroindah, tanggal 20 Setember 2017.

Putusan Pengadilan Negeri Jakarta Pusat No. 123/Pid.Sus/2017/PN Jkt.Pst perihal tindak pidana korupsi karena mengakibatkan kerugian negara yang berasal dari musnahnya atau berkurangnya ekologis/lingkungan oleh Gubernur Sulawesi Utara.

Geer v. Connecticut, 161 U.S. 519 (1896).

Dep't of Fisheries v. Gillette, 27 Wn. App. 815, (Wash. Ct. App. 1980).

State ex rel. Bacich v. Huse, 187 Wn. 75, (Wash. 1936).

Judd v. Bernard, 49 Wn. 2d 619, (Wash. 1956).

State ex Rel. Campbell v. Case, 182 Wn. 334, (Wash. 1935). 
Landasan Doktriner Hak Gugat Pemerintah Terhadap Kerugian Lingkungan Hidup di Indonesia

Hughes v. Oklahoma, 441 U.S. 332 (1976).

Sierra Club v. Morton, 405 U.S. 727 (1972)

Toomer v. Witsell, 334 U.S. 385 (1948).

Maryland v. Amerada Hess Corp., 350 F. Supp. 1060 (D. Md. 1972).

Louisiana v. Texas, 176 U.S. 1 (1900).

Georgia v. Tennessee Copper Co., 206 U.S. 230 (1907).

Illinois Central Railroad v. Illinois, 146 U.S. 387.

State v. Jersey Central Power Light Co., 125 N.J. Super. 97, 103 (N.J. Super. App. Div. 1973).

Snapp \& Son, Inc. v. Puerto Rico ex rel. Barez, 458 U.S. 592 (1982). 